\title{
Getting back to Scenario Planning: Strategic action in the Future of Energy Europe
}

\author{
Henrik Blomgren ${ }^{1}$, Peder Jonsson ${ }^{2}$, Fredrik Lagergren ${ }^{3}$ \\ ${ }^{1}$ Industrial Economics and Management, INDEK \\ Royal Institute of Technology, Sweden \\ Henrik.blomgren@indek.kth.se \\ ${ }^{2}$ KreabGavinAnderson, Sweden \\ ${ }^{2}$ pjonsson@ kreabgavinanderson.com \\ ${ }^{3}$ KTH Executive School \\ Royal Institute of Technology, Sweden \\ Fredrik.lagergrendes.kth.se
}

\begin{abstract}
Scenario planning is a commonly used method in order to analyse complex aspects of the energy system. Historically it has been an important tool to prepare for long-term action. Today however, due to the deregulated market, it could be assumed that scenario analysis is abandoned. Maybe more (the only) attention is on short-term action.

This paper presents a review over the time period of 1970 to 2010 on scenario-planning articles. The overall purpose is to evaluate how historical scenario studies stand in a situation of today's deregulated energy markets.

Articles surveyed are published in well-respected and internationally well-spread peer-reviewed journals. Focus is put on 1, when, and by whom, articles have been published 2, for what reasons projects have been taken and with what method 3 , what aspect that have been in focus. The articles are also analysed in terms of possible use in today's deregulated situation.

Three conclusions are drawn. Firstly, the main use of scenario planning still tends to be a support to political processes. Secondly, three major issues and drivers for change dominate when different aspects of the energy system are analysed in scenario projects: climate change, security in terms of demand/supply and economic development. Thirdly, it is concluded that scenario planning still tend to be of value when analysing the future of the deregulated energy sector in Europe.

However, in order to be fully utilized for the future scenario methodology must take into account that energy industry actors are not being controlled by politics as they where during the regulated period.
\end{abstract}

\section{INTRODUCTION}

Scenario planning is a commonly used method in order to analyse the energy system [1] - [3]. Historically it has been an important tool for politicians, academia and industry to analyse complex issues and prepare for long-term action [4] [7]. Over time the method have been debated, for misuse as well as for it's meaning [8], [9]. Still it is said to be of major interest and used in practice [10].

During the last decade however, due to an increase of deregulated energy markets, it can be assumed that market oriented short-term action have increased. Major structural changes appear on international level. This could mean that long-term strategic thinking, thereby scenario planning, is becoming obsolete, even left behind [11]. In this paper a literature review is presented in order to analyse if that is the case.

The paper presents an extensive review of energy scenario literature published between 1970 and 2010. The aim is to identify groups of studies as well as to categorize them and to evaluate their possible use in a deregulated environment. The review is based on a sampling of important articles, which mirror the major streams of academic interest over the years.

\section{REVIEW METHODOLOGY}

Energy scenario projects are published in the crossroad of engineering and social sciences and also to be found under different headlines. The term "scenario", as such, can also be utilized as a common buzzword for "future in general" but without a scenario methodology applied behind. Here we define scenarios as focused description of different futures. This is a definition in line with [12] even though we broaden our scope, also including non-narrative scenario projects.

With our broad definition there is a need for an identification process of articles clarified in three steps. First, a broad round of analysis was made in order to; $\mathrm{A}$. Test possible search terms, B. Generate hypotheses for suitable search method, and C. Identify possible journals of interest. Second, a focused analysis was made in order to; 1 . Define final search terms, 2. Establish Method, 3. Identify targeted journals. Third, the articles were collected, categorized and analysed.

\section{A. Establishing method}

The sampling of articles was collected with the help of the electronic journal database "Scopus" (covering about 18,000 titles from more than 5,000 publishers). The initial scope was 
broadly set for articles with "Energy" and "Scenario" included in "Title" as well as in "Abstract" and "Keywords". Journals included were categorized under the umbrella of "Physical Sciences" ( $>7200$ titles) as well as "Social Sciences \& Humanities" (>7300 titles). Journals like "Astrophysical Journal", "Physical Review" and "Physical Letters" was manually excluded in order to exclude the use of "scenario" as a term used for purely technology oriented topics.

The result revealed 1232 articles presented in Table 1.

TABLE I

JOURNALS WHERE SCENARIO TERMS ARE REVEALED

\begin{tabular}{|c|c|c|c|c|c|}
\hline $\begin{array}{l}\text { Journal } \\
\text { Amount of } \\
\text { articles }\end{array}$ & $\begin{array}{l}1970- \\
1979\end{array}$ & $\begin{array}{l}1980- \\
1989\end{array}$ & $\begin{array}{l}1990- \\
1999\end{array}$ & $\begin{array}{l}2000- \\
2010\end{array}$ & Sum \\
\hline Energy Policy & 7 & 8 & 68 & 458 & 541 \\
\hline $\begin{array}{l}\text { Energy - The } \\
\text { International } \\
\text { Journal }\end{array}$ & 13 & 27 & 44 & 132 & 216 \\
\hline $\begin{array}{l}\text { Renewable } \\
\text { Energy }\end{array}$ & - & - & 16 & 62 & 78 \\
\hline $\begin{array}{l}\text { Applied } \\
\text { Energy }\end{array}$ & 1 & 2 & 18 & 53 & 74 \\
\hline $\begin{array}{l}\text { Renewable } \\
\text { and } \\
\text { Sustainable } \\
\text { Reviews }\end{array}$ & - & - & - & 73 & 73 \\
\hline $\begin{array}{l}\text { Energy } \\
\text { Economics }\end{array}$ & 1 & 5 & 14 & 53 & 73 \\
\hline $\begin{array}{l}\text { International } \\
\text { Journal of } \\
\text { Global } \\
\text { Energy Issues }\end{array}$ & - & - & 22 & 45 & 67 \\
\hline $\begin{array}{l}\text { Energy } \\
\text { Conversion } \\
\text { and } \\
\text { Management }\end{array}$ & - & 2 & 20 & 41 & 63 \\
\hline $\begin{array}{l}\text { Climate } \\
\text { Change }\end{array}$ & 2 & 4 & 1 & 40 & 47 \\
\hline Sum & 24 & 48 & 203 & 957 & 1232 \\
\hline
\end{tabular}

The survey revealed a clear overweight of articles in "Energy Policy" and "Energy" indicating these journals to be of biggest interest. The dominance of "Energy Policy" however, at least to some extent, is explained by its increase of size over last decade. In 1973 only 39 articles were published in "Energy Policy", by 1983 "Energy Policy" published 93 articles, and by 2010 more than 740 articles was published (1993, 113; 2003, 141).

The survey also revealed journals that normally are categorized within the field of "Economics", and by Scopus classified under the umbrella of "Social Sciences \& Humanities" (like "Energy Economics"). At the same time a journal like "Energy Policy", by Scopus classified under the umbrella of "Physical Sciences", was revealed. This confirms that scenario projects are published in the crossroad of engineering and social sciences.

In order to get a clearer picture of the sampling of the 1232 articles and the journals respective importance, the top 19 articles with more than 15 citations was analysed, see
Appendix A. 8 of these articles where published in "Energy policy". The result emphasised a need for a further focusing towards "Energy policy". At the same time Appendix A also revealed that several influential articles do not have a scenario project focus, according our definition. The result confirms that the term "scenario" occasionally is used synonymously with "future in general".

\section{B. Identifying targets}

For the second round of identification process the scope was limited towards the terms "Scenario" AND "Energy" included in "Titles". The result is revealed in Table 2.

TABLE 2

JOURNALS WHERE SCENARIO PROJECTS ARE PUBLISHED

\begin{tabular}{|l|}
\hline $\begin{array}{l}\text { Journals where search terms "Scenario" AND "Energy } \\
\text { appear in the titles - over the whole period of 1970 - 2010 } \\
\text { (Amounts of articles) }\end{array}$ \\
\hline - Energy Policy (61) \\
\hline - Energy (17) \\
\hline - International Journal of Global Energy Issues (12) \\
\hline - Revue De L Energie (10) \\
\hline - Technological Forecasting and Social Change (9) \\
\hline - Renewable and Sustainable Energy Reviews (7) \\
\hline - Physical Review D Particles Fields Grav. and Cosmology (7) \\
\hline - Futures (6) \\
\hline - Renewable Energy (5) \\
\hline - Applied Energy (4) \\
\hline - Biomass and Bioenergy (4) \\
\hline - Long Range Planning (4) \\
\hline - Ecological Economics (4) \\
\hline - Building and Environment (3) \\
\hline - Environmental Science and Policy (3) \\
\hline - Energy and Buildings (3) \\
\hline - Physical Review D (3) \\
\hline - European Journal of Operational Research (3) \\
\hline - Physical Review B Condensed Matter and Mat. Physics (3) \\
\hline - Fusion Engineering and Design (3) \\
\hline - Energy Conversion and Management (3) \\
\hline - Nuclear Engineering and Design (3) \\
\hline - International Journal of Hydrogen Energy (3) \\
\hline - VDI Berichte (3) \\
\hline - International Journal of Energy Research (3) \\
\hline - 2010 7th International Conference on the European Energy \\
Market EEM 2010 (3) \\
\hline
\end{tabular}

Journals like "Energy policy" and "Energy" also end up on top of this list, emphasizing the assumption of these journals to be of biggest interest.

Interesting result with this sampling is however that "Energy Economics", revealed within the first round of analysis, does not appear at all on the list. Journals like "Energy policy" and "Energy" dominated the result with "International Journal of Global Energy Issues" on third position. This reveals that within the field of "Economics" the term "scenarios" often is used without a scenario methodology project behind. It seems that it is not unusual within the field of Economics to do mathematical oriented scenarios on one hand as well as using the term synonymously for "future in general" on the other. 
The "International Journal of Global Energy issues" is however not part of the pattern of journals with most cited articles analysed within the first round of analysis (Appendix A). It also came out on place 7 within Table 1 during the first round of analysis. This confirms the previously raised assumption of "Energy policy" and "Energy" to be of biggest interest for our purpose.

With this result shown it was decided to limit the final sampling of articles to be included within the analysis towards the 78 articles published within "Energy policy" and "Energy" (top two journals in Table 1 and Table 2). Since this review only is made with the purpose to mirror the major stream of energy scenarios the sampling made is considered as valid.

\section{DATA COLLECTION}

The 78 articles included in the review are collected from "Energy Policy" and "Energy", see [13] - [90]. They are published according the pattern shown in Table 3.

TABLE 3

YEAR AND AMOUNT OF PUBLICATION

\begin{tabular}{|c|c|c|c|c|c|c|}
\hline Articles & $\begin{array}{l}1970- \\
1979\end{array}$ & $\begin{array}{l}1980- \\
1989\end{array}$ & $\begin{array}{l}1990- \\
1995\end{array}$ & $\begin{array}{l}1995- \\
2000\end{array}$ & $\begin{array}{l}2000- \\
2005\end{array}$ & $\begin{array}{l}2005- \\
2010\end{array}$ \\
\hline $\begin{array}{l}\text { Year } \\
\text { (number } \\
\text { of } \\
\text { articles) } \\
\text { published } \\
\text { that year) }\end{array}$ & $\begin{array}{l}1978 \\
(1) \\
1977 \\
(1)\end{array}$ & $\begin{array}{l}1983 \\
(2) \\
1981 \\
(1)\end{array}$ & $\begin{array}{l}1994 \\
(2) \\
1993 \\
(4) \\
1991 \\
(5) \\
1990 \\
(1)\end{array}$ & $\begin{array}{l}1998 \\
(2) \\
1997 \\
(1) \\
1996 \\
(1)\end{array}$ & $\begin{array}{l}2005 \\
(1) \\
2004 \\
(1) \\
2003 \\
(5) \\
2001 \\
(3) \\
2000 \\
(1)\end{array}$ & $\begin{array}{l}2010 \\
(15) \\
2009 \\
(9) \\
2008 \\
(10) \\
2007 \\
(9) \\
2006 \\
(3) \\
2005 \\
(1)\end{array}$ \\
\hline Total & 2 & 3 & 12 & 4 & 11 & 47 \\
\hline
\end{tabular}

A decrease in the number of publications can be observed during end of 1990s with an increase around 2005 and further on. By that, it can be observed that the pattern for publication roughly follows the pattern of the deregulation process.

Truly, it is complicated to tell exactly when deregulation "started" [102], [109]. Normally deregulation is a long process ongoing over time including several changes of regulations in several subareas of an industry [110]. Sometimes it even includes the setting up of rules, which formally did not exist before deregulation. If comparing for instance the electricity and the natural gas markets these differences are shown where clear [111] - [113].

However, it could be claimed that deregulation in countries like UK and Norway started around 1993, in countries like Sweden 1996. At EU-level as whole it started around $2001-2003$, and still is ongoing [114]. In countries like USA the process of deregulation started earlier [99], [101]. By that it could also be claimed the pattern of publications to follow the deregulation process.
Authors and affiliations with more than one article published are shown in Table 4. Neither any author nor any research group dominates the area. Biggest amount of articles are published by Wolfram Krewitt at the "Deutsches Zentrum for Luft- und Ruamfart" in Stuttgart, Germany, see [52] - [54].

TABLE 4

AUTHORS, AFFILIATION AND RESEARCH GROUP

\begin{tabular}{|l|l|}
\hline $\begin{array}{l}\text { Author (Amount } \\
\text { of articles } \\
\text { published) }\end{array}$ & $\begin{array}{l}\text { Affiliation/Research Group (Amount } \\
\text { of articles) }\end{array}$ \\
\hline Krewitt, W. (3) & Chalmers Tekniska Högskola (3) \\
Graus, W.(2) & Lawrence Berkeley National Lab. (3) \\
Schafer, O. (2) & Deutsches Zentrum fur Luft- Und \\
Phdungsilp, A. (2) & Raumfahrt (3) \\
Simon, S. (2) & Paul Scherrer Institut (3) \\
Strachan, N. (2) & UC Berkeley (3) \\
Teske, S. (2) & Ecofys (2) \\
Turton, H. (2) & Greenpeace International (2) \\
Browne, D. (2) & European Renewable Energy Council \\
Koomey, J.G. (2) & (2) \\
Berntsson, T. (2) & Dhurakij Pundit University (2) \\
Barreto, L. (2) & Zhejiang University (2) \\
Abreu, S.L. (2) & Universität Bochum (2) \\
Zervos, A. (2) & University of Limerick (2) \\
Martins, F.R. (2) & Inst. Nacional de Pesquisas Espac. (2) \\
Kypreos, S. (2) & Univers. Federal de Santa Catarina (2) \\
Simon, S. (2) & UCL (2) \\
Strachan, N. (2) & University of Oxford (2) \\
Teske, S. (2) & Instituto Federal de Educação, Ciěncia \\
Turton, H. (2) & e Tecnológia de Santa Catarina (2) \\
Browne, D. (2) & \\
Koomey, J.G. (2) & \\
Berntsson, T. (2) & \\
Barreto, L. (2) & \\
Abreu, S.L. (2) & \\
Zervos, A. (2) & \\
Martins, F.R. (2) & \\
Kypreos, S. (2) & \\
\hline
\end{tabular}

\section{A TYPOLOGY OF THE LITERATURE}

Our analysis is influenced by the typology used by [91] even though developed post hoc and used with different purpose. The typology reveals distinct categories even though overlapping types of scenario projects concerning geography, scope of interest, methodologies, and time perspective, exist.

\section{A. Geographical interest: national, regional, global}

Most scenario projects analyzed covers a geographical area or analyze a certain problem from a geographical perspective point of view (66 out of 78). 42 of them cover 26 singular countries, 9 are regional and 15 supranational see Table 5 .

During the 1970s and 1980s, the interest was related to singular countries, like Germany and New Zealand. The scope has been broadened over time, gradually for instance also covering Russia and China. However, it was not until 1990 when the first article covering the whole of Europe was published [33]. The first article covering the globe as a whole was published 1993 [85]. The first article covering China was published as late as 2003 [86]. 
TABLE 5

GEOGRAPHICAL SCOPES AND AMOUNT OF ARTICLES

\begin{tabular}{|c|c|c|c|}
\hline $\begin{array}{c}\text { Geographical } \\
\text { scope }\end{array}$ & $\begin{array}{c}\text { Amount } \\
\text { of articles }\end{array}$ & $\begin{array}{c}\text { Geographical } \\
\text { Scope }\end{array}$ & $\begin{array}{c}\text { Amount } \\
\text { of articles }\end{array}$ \\
\hline National & $42 \mathrm{sum}$ & Regional & 9 sum \\
\hline China & 6 & California & \\
\hline Germany & 4 & Bangkok & 2 \\
\hline India & 3 & West- & 1 \\
\hline Brazil & 3 & Germany & 1 \\
\hline USA Irland & 2 & Shanghai & 1 \\
\hline Mexico & 1 & Irish city & 1 \\
\hline UK & 2 & Himalaya & 1 \\
\hline New Zealand & 2 & Aalborg & \\
\hline Malasia & 1 & Eastern- & 1 \\
\hline USSR & 1 & Russia & \\
\hline Korea & 1 & & \\
\hline Norway & 1 & $\underline{\text { Supranational }}$ & 15 sum \\
\hline Sweden & 1 & Global & 8 \\
\hline Portugal & 1 & Europe & 3 \\
\hline Switzerland & 1 & East. Europe & 1 \\
\hline Austria & 1 & Middle East & 1 \\
\hline Jordan & 1 & Asia & 1 \\
\hline Turkey & 1 & OECD & 1 \\
\hline Libanon & 1 & & \\
\hline Laos & 1 & & \\
\hline Thailand & 1 & & \\
\hline Australia & 1 & & \\
\hline Eritrea & 1 & & \\
\hline Taiwan & 1 & & \\
\hline South Africa & 1 & & \\
\hline
\end{tabular}

B. Issues of interest: Transportation, housing, industry, security of supply - and climate change

As mentioned; a certain amount of articles does have an interest to analyse a whole future situation - like a country, a region or the whole globe - or apply its issue of interest in a geographical setting (or as a case). To some extent topics of interest do overlap with a geographical focus.

One segment of interest is the three dominating sectors for energy use, meaning: housing, transportation and the industry sector (14 out of 78). Occasionally also specific sectors are in focus, like agriculture [34].

Another segment of interest are future supply and the future for different energy sources like for instance oil, water, wind, nuclear and bio energy (19 out of 78). Certain specific energy source technologies have also been identified like fuel cells [54], energy storage [80], pulp-mills [48], waste energy [69] or solar cells [58].

The main aspect of interest is however climate change issues in different forms, like energy efficiency need [88], renewable resources in a broad sense [39], [57], policy requirements [43] and policy implications [81]. Within that category 29 articles was identified. Surprisingly, not that many of them relate explicitly to the work made by IPCC [66].

This group of articles can be divided in two sub-categories: articles where climate change issues is the main topic and articles where it is one out of two important aspects (the other one most commonly used is economic constraints). It is also interesting to observe the limited interest in connecting climate change with security of supply. This has sometimes been claimed to be one main reason for China being interested in renewable energy resources [115], [116].

Articles where climate change is considered as one, out of several, important aspects of the energy system, are thereby categorized under other headlines. In nearly all articles published during the last decades the climate change issue is touched upon one way or another. For identified articles within each category see Table 6 .

TABLE 6

ARTICLES CLASSIFIED CONCERNING ISSUE OF INTEREST

\begin{tabular}{|l|l|}
\hline \multicolumn{1}{|c|}{ Issue of interest } & Examples of articles \\
\hline $\begin{array}{l}\text { Climate change, } \\
\text { The main issue: }\end{array}$ & {$[17],[21],[23],[24],[25],[26],[28],[39]$,} \\
\hline & {$[42],[53],[56],[57],[60],[62],[67],[70]$,} \\
$\begin{array}{l}\text { Climate change, } \\
\text { One, out of two: }\end{array}$ & {$[78],[82],[84],[85],[86],[87],[88]$} \\
\hline Housing & {$[27],[33],[66],[72],[77],[79]$} \\
\hline Transportation & {$[14],[20],[40],[67],[75],[76]$} \\
\hline Industry & {$[19],[88]$} \\
\hline $\begin{array}{l}\text { Security of supply }[89] \\
\text { and energy } \\
\text { sources }\end{array}$ & {$[15],[16],[31],[33],[38],[41],[44],[45]$,} \\
\hline $\begin{array}{l}\text { Certain energy } \\
\text { technologies }\end{array}$ & {$[46],[47],[50],[58],[59],[69],[71],[73]$,} \\
\hline
\end{tabular}

\section{Methodological differences: Forecasts, Exploratory} studies and Visions, Back casting and Roadmaps

From a methodological point of view the literature can be categorized in six streams of approaches, see Table 7. The dominating use is forecasting, back casting and roadmaps.

Forecasting studies are made with a given basic situation as a starting point and thereafter parameters, normally a limited amount of (most commonly only one), are added in order to predict a future situation.

TABLE 7

ARTICLES CLASSIFIED WITH DIFFERENT METHODOLOGICAL APRROACHES

\begin{tabular}{|l|l|}
\hline Methodology & Examples of articles \\
\hline Forecasts & $\begin{array}{l}{[13],[14],[22],[25],[26],[30],[31],[34],} \\
{[38],[47],[49],[52],[55],[56],[61],[63],} \\
{[65],[67],[68],[70],[81],[84],[89]}\end{array}$ \\
\hline $\begin{array}{l}\text { Back casting and } \\
\text { roadmaps }\end{array}$ & $\begin{array}{l}{[15],[17],[20],[21],[23],[24],[28],[37],} \\
{[42],[50],[52],[60],[62],[70],[73],[78],} \\
{[85],[86]}\end{array}$ \\
\hline $\begin{array}{l}\text { Exploratory } \\
\text { studies and } \\
\text { visions }\end{array}$ & {$[19],[24],[27],[35],[41],[44],[77],[86]$} \\
\hline $\begin{array}{l}\text { Assessments and } \\
\text { evaluations of } \\
\text { previously made } \\
\text { scenarios }\end{array}$ & {$[16],[23],[32],[33],[44],[56],[66],[69]$,} \\
\hline $\begin{array}{l}\text { Developing } \\
\text { methodology }\end{array}$ & {$[26],[57],[58],[82]$} \\
\hline $\begin{array}{l}\text { Utilising existing } \\
\text { models }\end{array}$ & {$[40],[46],[75],[79],[82],[83],[87]$} \\
\hline
\end{tabular}


The characteristics for back casting and road maps is having a clear target as starting point, like for instance a perceived need to adapt to climate change issues (the most common case). These projects are made in order to investigate how to avoid, or achieve, a certain future. Back casting studies work their way backwards with a target set as starting point in order to visualise for instance what kind of actions are needed to achieve the target. Roadmaps are investigating the way forward.

It is uncommon that several approaches are used simultaneously even though it exist, [37] and [70].

Exploratory and vision studies utilise a more open methodology, mainly with the purpose to explore possible - in stead of wished for or expected to be - futures. Common is to sketch several different futures with the help of a script and a narrative approach utilising several parameters simultaneously.

This exploratory method is also an approach commonly used in more business oriented settings in order to analyse complex matters [92], [93], [94].

Close to the articles with exploratory or vision approach other purposes for contribution, than affecting or understanding future, have also been identified. Several projects have partly been made in order to test and develop energy scenario methodology as such. In Table 7 they are categorized as "developing methodology".

There are also several articles where the purpose is to assess and evaluate scenario projects, or for instance utilizing baseline scenarios, previously made by others. Already existing cost-optimization models, like "Eclipse", the "Markal-model" or "TIMES PT-model", have been used. These articles have been categorized as "utilizing existing models" in Table 7.

\section{Different time perspectives}

Future easily becomes a fluffy word. The applied time perspective is therefore of importance to bring forward. The timeframes utilized are normally either about 10 years long or far longer than so, about $30-60$ years. The longest timeframe is 100 years [66], [86]. Occasionally articles do have unspoken time targets for their study. Table 8 reveal articles within different time frames.

TABLE 8

STUDIES CLASSIFIED IN DIFFERENT TIME FRAMES APPLIED

\begin{tabular}{|l|l|}
\hline \multicolumn{1}{|c|}{ Time frame } & Examples of articles \\
\hline $\begin{array}{l}10-20 \text { year long } \\
\text { perspective }\end{array}$ & {$[19],[24],[32],[34],[63],[64],[67],[73]$,} \\
\hline $20-30$ years & {$[79]$} \\
\hline $30-50$ years & {$[14],[16],[36],[41],[48],[50],[56],[69]$,} \\
& {$[13],[76],[81],[88],[89]$} \\
\hline $50-100$ years & {$[52],[72],[78],[87],[49],[44],[45],[47]$,} \\
\hline
\end{tabular}

\section{WHAT DOES THE LITERATURE SAY ABOUT STRATEGIC ACTION?}

Implicitly, or explicitly, every kind of future oriented analysis is based on a perception on how strategic action occurs [95], [96]. When doing scenario studies, future is always considered "as if to be driven" by different kind of forces - often considered as to be in the hands of different kind of actors [97], [98]. These forces can be elaborated within a scenario project, most explicitly made within explorative projects. They can also be taken for granted and thereby be used as a foundation for the study as such (most straightforward articulated in forecasts).

Most common within the articles reviewed is an embedded perception where the dominating actor influencing the future of the energy system is the policy actor. This is either raised very explicitly, see for instance [17], [25], [28], [60], [67], [82], [88] or utilized implicitly, see [39], [42], [86], [87].

When it comes to drivers for change in future an overall view can thereby be achieved by categorizing the articles in three streams: projects where climate change, economic development or security of supply is perceived as the main underlying drivers affecting future. The dominating aim, often explicit but sometimes implicit, is the request for policy action and to bring forward conclusions relevant from a policy point of view.

The issue of interest for doing the scenario projects can also be divided between push and pull oriented driven aspects concerning future. Examples of push are perceived increase of population [37], [73], the future of living standards [35], [74] or a need for economic development [30] - assumed to be putting pressure upon the energy system from the outside. Examples of pull oriented driven aspects are supply [42] and pricing [55] - issues changing the system from the inside. Historically the industrial actor, in this respect, has been considered as an "insider". Deregulation has made industry partly becoming an "outsider".

\section{DISCUSSION CONCERNING THE LITERATURE AND A DEREGULATED MARKET}

In the pure world of "Economics"; when markets are deregulated the former nationally controlled actor is becoming an independent actor. In several cases, like in the energy sector, there do however still exist, and have always existed, important strings attached towards industry from governments. This could be about ownership, new regulations being set up, control of capital needed etc [99], [100], [101]. This mean that policy action still has a huge impact on the energy system, but not the same way as during regulated times [102].

Compared to a previously regulated environment the industrial actor is given far bigger possibilities to act "of its own". In many cases the industrial actor, as such, is therefore to be considered as an actor affecting the energy system. It is not only being a marionette within the hands of governments and a "consequence of issues developed by others".

Due to the deregulation of the European energy market it is therefore of interest to observe that it, still, is rare with scenario projects concerning the industrial energy actors, even though such articles exist [19], [36], [48], [50], [54] and [64].

It is also of interest to notice that most scenario projects published still are based on the assumption of the energy 
actors being in control in the hands of governments. No articles have been identified where the industrial actor, as such, have been taken into account as one of the main drivers for change or as an actor/parameter "interfering" towards other possible actors. Neither have articles where industrial oriented scenario work has been influential, been identified.

There do however on one hand for instance exist several references within our reviewed literature towards early scenario work made by Shell scenario unit during 1970s, 1980s and 1990s, [1], [96], or [98]. This is an industrial thinktank well known in industry as well as in the policy area. On the other hand: none of the reviewed articles seem to have been influenced by Shell when accomplishing their projects.

Within the European market of today we can observe former national actors having done tremendously big amounts of mergers and acquisitions during the last ten years. They have ended up becoming international actors acting across national boarders, [103], [104]. It is clear that the industrial actors today are forces "interfering with future" in many different ways since deregulation started. For example they have started to unbundle their own value chain [105] - [107].

Maybe the exploratory methodology could be widely used when developing new knowledge concerning the energy system in such direction. This is a rather open approach and opens up for bigger possibilities of elaborating with several different forces and actors simultaneously.

Still, the topics revealed in the review are of relevance, even within a deregulated energy market.

\section{CONCLUSIONS}

This article has presented a literature review concerning the major streams of publications of scenario projects during 1970 - 2010 published within "Energy policy" and "Energy". The review has shown a continuous interest in scenarios, even though the European, as well as many other energy markets, have been deregulated. There was a short decline of articles during the start of the deregulation process but then the amounts of publications grew again.

The interest within energy scenario projects over the years seem to be rather stable, even though geographical interest have been broadened as well as a growing interest in climate issues have been shown. Under that stream of interest, there is an ongoing interest utilizing traditional scenario methodology - not the least: forecasting, back casting and road maps. Issues like climate change, demand and supply, security of supply as well energy sources have been of interest. The three dominating sectors utilizing energy (transportation, housing and industry) are also common topics of interest.

The analysis being made has also shown that the interest of scenarios is more theoretically oriented compared towards its interest of scenario practice within, and for, industry. It is concluded that the use of scenario planning within the energy business is notably lacking of research. Conclusions recently made by [10] are thereby supported.

It is also concluded that the main interest within academia concerning energy scenarios still is directed towards policy action. Explicitly, or implicitly, the industrial actors are perceived as acting as if they where being marionettes within the hands of the political systems. A major drawback with recent research is that it still does not embed the industrial actor as one of the actors "interfering" with the energy system.

It is therefore suggested that future research concerning energy scenarios start considering, as well as embed, the industrial actor - as an industrial actor. This could for instance be made by an increasing use of exploratory approaches. As claimed before: Energy Scenarios should be considered as a learning process [108].

APPENDIX A. TOP RANKED PUBLICATIONS WITHIN THE BROAD SCOPE DURING INITIAL SURVEY

\begin{tabular}{|c|c|}
\hline $\begin{array}{l}\text { Articles within the sampling of } 1232 \text { articles where } \\
\text { search terms "Energy" AND "Scenario" is } \\
\text { included in titel, abstract or keywords - with more } \\
\text { than } 15 \text { citations }\end{array}$ & $\begin{array}{l}\text { Cita- } \\
\text { tions }\end{array}$ \\
\hline $\begin{array}{l}\text { 1. Stabilizing greenhouse gas concentrations at } \\
\text { low levels: An assessment of reduction strategies and } \\
\text { costs, Van Vuuren, D.P., Den Elzen, M.G.J., Lucas, } \\
\text { P.L., Eickhout, B., Strengers, B.J., Van Ruijven, B., } \\
\text { Wonink, S., Van Houdt, R. } 2007 \text { Climatic Change } 81 \\
\text { (2), pp. } 119-159\end{array}$ & 64 \\
\hline $\begin{array}{l}\text { 2. Renewable energy sources: Their global } \\
\text { potential for the first-half of the } 21 \text { st century at a } \\
\text { global level: An integrated approach, de Vries, } \\
\text { B.J.M., van Vuuren, D.P., Hoogwijk, M.M. } 2007 \\
\text { Energy Policy } 35 \text { (4), pp. } 2590 \text { - } 2610\end{array}$ & 48 \\
\hline $\begin{array}{l}\text { 3. Scenarios for a clean energy future, Brown, } \\
\text { M.A., Levine, M.D., Short, W., Koomey, J.G. } 2001 \\
\text { Energy Policy } 29 \text { (14), pp. 1179- } 1196\end{array}$ & 37 \\
\hline $\begin{array}{l}\text { 4. Multi-gas scenarios to stabilize radiative } \\
\text { forcing, van Vuuren, D.P., Weyant, J., de la } \\
\text { Chesnaye, F. } 2006 \text { Energy Economics } 28 \text { (1), pp. } \\
\text { 102-120 }\end{array}$ & 35 \\
\hline $\begin{array}{l}\text { 5. Abatement costs of post-Kyoto climate } \\
\text { regimes, den Elzen, M., Lucas, P., van Vuuren, D. } \\
2005 \text { Energy Policy } 33 \text { (16), pp. } 2138-2151\end{array}$ & 33 \\
\hline $\begin{array}{l}\text { 6. The consistency of IPCC's SRES scenarios to } \\
\text { recent literature and recent projections, Van Vuuren, } \\
\text { D.P., O'Neill, B.C. } 2006 \text { Climatic Change } 75 \text {, pp } 9\end{array}$ & 29 \\
\hline $\begin{array}{l}\text { 7. Models for mid-term electricity demand } \\
\text { forecasting incorporating weather influences, } \\
\text { Mirasgedis, S., Sarafidis, Y., Georgopoulou, E., } \\
\text { Lalas, D.P., Moschovits, M., Karagiannis, F., } \\
\text { Papakonstantinou, D. } 2006 \text { Energy } 31 \text { (23), pp 208- } \\
227\end{array}$ & 29 \\
\hline $\begin{array}{l}\text { 8. Technological learning for carbon capture and } \\
\text { sequestration technologies, Riahi, K., Rubin, E.S., } \\
\text { Taylor, M.R., Schrattenholzer, L., Hounshell, D. } \\
\text { 2004 Energy Economics } 26 \text { (4), pp. } 539-564\end{array}$ & 29 \\
\hline $\begin{array}{l}\text { 9. Exploring the ancillary benefits of the Kyoto } \\
\text { Protocol for air pollution in Europe, van Vuuren, } \\
\text { D.P., Cofala, J., Eerens, H.E., Oostenrijk, R., Heyes, } \\
\text { C., Klimont, Z., den Elzen, M.G.J., Amann, M. } 2006 \\
\text { Energy Policy } 34 \text { (4), pp. } 444 \text { - } 460\end{array}$ & 25 \\
\hline $\begin{array}{l}\text { 10. Energy and emission scenarios for China in the } \\
21 \text { st century - exploration of baseline development }\end{array}$ & 25 \\
\hline
\end{tabular}


and mitigation options, van Vuuren, D., Fengqi, Z., de Vries, B., Kejun, J., Graveland, C., Yun, L. 2003 Energy Policy 31 (4), pp. $369-387$

11. Using energy scenarios to explore alternative energy pathways in California, Ghanadan, R., Koomey, J.G. 2005 Energy Policy 33 (9), pp. 1117 1142

12. Oil and nuclear power: Past, present, and future, Toth, F.L., Rogner, H.-H. 2006 Energy Economics 28 (1), pp. $1-25$

13. Prospects for carbon capture and sequestration technologies assuming their technological learning, Riahi, K., Rubin, E.S., Schrattenholzer, L. 2004 Energy $29(910-1309)$

14. Air pollution from energy use in a developing country city: The case of Kathmandu Valley, Nepal, Shrestha, R.M., Malla, S. 1996 Energy 21 (9),785 794

15. Responses to technology and taxes in a simulated world, van Vuuren, D.P., de Vries, B., Eickhout, B., Kram, T. 2004 Energy Economics 26 (4), pp. 579-601

16. Savings estimates for the Energy $\operatorname{Star} \AA$ voluntary labeling program, Webber, C.A., Brown, R.E., Koomey, J. 2000 Energy Policy 28 (15), pp. 1137-1149

17. Future electric power technology choices of Brazil: A possible conflict between local pollution and global climate change, Schaeffer, R., Salem Szklo, A. 2001 Energy Policy 29 (5), pp. 355.369

18. Regional abatement action and costs under allocation schemes for emission allowances for achieving low CO2-equivalent concentrations, Den Elzen, M.G.J., Lucas, P.L., Van Vuuren, D.P. 2008 Climatic Change 90 (3), pp. 243-268

19. Potential of Kyoto protocol clean development mechanism in transfer of clean energy technologies to small island developing states: Case study of Cape Verde, Duic, N., Alves, L.M., Chen, F., Da Graça Carvalho, M. 2003 Renewable and Sustainable Energy Reviews 7 (1), pp. 83-98

\section{REFERENCES}

[1] De Geus A., P, The Living Company, Nicholas Brealey, 1999.

[2] Ellis A, Bowitz E., \& Roland K., Structural challenge in Europe's gas markets: three scenarios for the development of the European gas market to 2020, Energy Policy 28, pp 297 $309,2000$.

[3] Silberglitt R., Hove A., Shulman P., Analysis of US energy scenarios: Meta-scenarios, pathways and policy implications, Technological Forecasting \& Social Change, 70, pp 297 - 315, 2003.

[4] DuMoulin, H, \& Eyre, J, Energy scenarios - a learning process, Energy economics, pp 73 - 86. 1979.

[5] Kahne A., Scenarios for Energy: Sustainable world vs mercantilism, Long Range Planning 25, pp 38 -46, 1992.

[6] Chermack T., J., Lynham S., A., A review of scenario planning literature, Future Research Quarterly, Summer, 7 -31, 2001.

[7] Schoemaker P., J., H., Scenario planning - a tool for strategic thinking, Sloan Management Review, 36, 25 - 40, 1995.
[8] Bradfielf, R., WrightG., Burt G., Cairns G., Heijden K., V., D., The origins and evolution of scenario techniques in long range business planning, Futures, 37, 795 - 812, 2005.

[9] Huss W., R., Honton E., J., Scenario planning - what style should you use, Long Range Planning, 20, 21 - 29, 1987.

[10] Bishop P., Hines A., Collins T., The current state of scenario planning: an overview of techniques, Foresight, 9, 5-25, 2007.

[11] Varum C., A., Melo C., Directions in scenario planning literature - A review of the past decades, Futures, 42, $355-$ 369,2010 .

[12] Schoemaker P., J., P., Multiple Scenario Development: Its conceptual foundation and behavioral foundations, Strategic Management Journal, vol 14, 193 - 213, 1993.

[13] Aggarwal, R. K., \& Chandel, S. S., Emerging energy scenario in western himalayan state of himachal pradesh. Energy Policy, $38(5), 2545-2551,2010$.

[14] Al-Hinti, I., Al-Ghandoor, A., Akash, B., \& Abu-Nada, E., Energy saving and $\mathrm{CO} 2$ mitigation through restructuring Jordan's transportation sector: The diesel passenger cars scenario. Energy Policy, 35(10), 5003-5011, 2007.

[15] Alberg Østergaard, P., Mathiesen, B. V., Möller, B., \& Lund, H., A renewable energy scenario for Aalborg municipality based on low-temperature geothermal heat, wind power and biomass. Energy, 35(12), 4892-4901, 2010.

[16] Aleklett, K., Höök, M., Jakobsson, K., Lardelli, M., Snowden, S., \& Söderbergh, B., The peak of the oil age - analyzing the world oil production reference scenario in world energy outlook 2008. Energy Policy, 38(3), 1398-1414, 2010.

[17] Anandarajah, G., \& Strachan, N., Interactions and implications of renewable and climate change policy on UK energy scenarios. Energy Policy, 38(11), 6724-6735, 2010.

[18] Audinet, P., \& Fages, E., Energy policy of India: Cost differences of two scenarios. Energy Policy, 26(9), 669-686, 1998.

[19] Axelsson, E., Harvey, S., \& Berntsson, T., A tool for creating energy market scenarios for evaluation of investments in energy intensive industry. Energy, 34(12), 2069-2074, 2009.

[20] Azar, C., Lindgren, K., \& Andersson, B. A., Global energy scenarios meeting stringent $\mathrm{CO} 2$ constraints - cost-effective fuel choices in the transportation sector. Energy Policy, 31(10), 961-976, 2003.

[21] Benestad, O., Energy and environment: Nordic energy scenarios for 2010 and 2030. Energy Policy, 21(12), 12251236, 1993.

[22] Bossel, H., \& Denton, R., Energy futures for the federal republic of Germany. three scenarios. Energy Policy, 5(1), 35$50,1977$.

[23] Boyle, S., A global fossil free energy scenario: Towards climate stabilization? Energy Policy, 22(2), 106-109, 1994.

[24] Brown, M. A., Levine, M. D., Short, W., \& Koomey, J. G., Scenarios for a clean energy future. Energy Policy, 29(14), 1179-1196, 2001.

[25] Browne, D., O'Regan, B., \& Moles, R., Use of multi-criteria decision analysis to explore alternative domestic energy and electricity policy scenarios in an Irish city-region. Energy, 35(2), 518-528, 2010.

[26] Browne, D., O'Regan, B., \& Moles, R., Use of ecological footprinting to explore alternative domestic energy and electricity policy scenarios in an Irish city-region. Energy Policy, 37(6), 2205-2213, 2009.

[27] Cantin, R., Mourtada, A., Guarracino, G., Adra, N., Nasser, M., \& Maamari, F., Scenarios of application of energy certification procedure for residential buildings in Lebanon. Energy Policy, 35(6), 3167-3178, 2007. 
[28] Chandler, W. U., Kolar, S., Gheorghe, A., \& Sitnicki, S., Climate change and energy policy in eastern Europe: Two scenarios for the future. Energy, 16(11-12), 1423-1435, 1991.

[29] Chen, T., Yu, O. S., Hsu, G. J., Hsu, F., \& Sung, W., Renewable energy technology portfolio planning with scenario analysis: A case study for Taiwan. Energy Policy, 37(8), 29002906, 2009.

[30] Cinar, D., Kayakutlu, G., \& Daim, T., Development of future energy scenarios with intelligent algorithms: Case of hydro in Turkey. Energy, 35(4), 1724-1729, 2010.

[31] Converse, A. O., The impact of large-scale energy storage requirements on the choice between electricity and hydrogen as the major energy carrier in a non-fossil renewables-only scenario. Energy Policy, 34(18), 3374-3376, 2006.

[32] Costa, R. C. D., Do model structures affect findings? two energy consumption and $\mathrm{CO} 2$ emission scenarios for brazil in 2010. Energy Policy, 29(10), 777-785, 2001.

[33] Costantini, V., Gracceva, F., Markandya, A., \& Vicini, G., Security of energy supply: Comparing scenarios from a European perspective. Energy Policy, 35(1), 210-226, 2007.

[34] Dhawan, K. C., Mittal, J. P., \& Bhullar, B. S., Energy scenario of Indian agriculture and its future requirements. Energy, 18(6), 657-664, 1993

[35] Diamond, R., A lifestyle-based scenario for US buildings: Implications for energy use. Energy Policy, 31(12), 1205-1211, 2003.

[36] Dobozi, I., Impact of market reforms on USSR energy consumption: Scenarios for the next decade. Energy Policy, 19(4), 303-324, 1991

[37] Eden, R. J., World energy to 2050. outline scenarios for energy and electricity. Energy Policy, 21(3), 231-237, 1993.

[38] Friedrichs, J., Global energy crunch: How different parts of the world would react to a peak oil scenario. Energy Policy, 38(8), 4562-4569, 2010

[39] Ghanadan, R., \& Koomey, J. G., Using energy scenarios to explore alternative energy pathways in California. Energy Policy, 33(9), 1117-1142, 2005.

[40] Gül, T., Kypreos, S., Turton, H., \& Barreto, L., An energyeconomic scenario analysis of alternative fuels for personal transport using the global multi-regional MARKAL model (GMM). Energy, 34(10), 1423-1437, 2009.

[41] Harris, G. S., Ellis, M. J., Scott, G. C., Wood, J. R., \& Phillips, P. H., Energy scenarios for new Zealand. Energy, 3(1), 1-14, 1978.

[42] Hennicke, P., Scenarios for a robust policy mix: The final report of the German study commission on sustainable energy supply. Energy Policy, 32(15), 1673-1678, 2004.

[43] Hoesung Lee, \& Ji-Chul Ryu., Energy and CO2 emissions in korea. long-term scenarios and related policies. Energy Policy, 19(10), 926-933, 1991

[44] Hollander, J. M., U.S. energy demand and supply scenarios: A retrospective appraisal of the U.S. national academy of sciences study by the committee on nuclear and alternative energy systems (CONEAS). Energy, 6(8), 699-725, 1981.

[45] Islas, J., Manzini, F., \& Martínez, M., Cost-benefit analysis of energy scenarios for the Mexican power sector. Energy, 28(10), 979-992, 2003.

[46] Jablonski, S., Strachan, N., Brand, C., \& Bauen, A., The role of bioenergy in the UK's energy future formulation and modelling of long-term UK bioenergy scenarios. Energy Policy, 38(10), 5799-5816, 2010

[47] Jeong, H., Kim, Y., Lee, Y., Ha, K., Won, B., Lee, D., et al., A 'must-go path' scenario for sustainable development and the role of nuclear energy in the 21st century. Energy Policy, 38(4), 1962-1968, 2010.

[48] Jönsson, J., Svensson, I, Berntsson, T., \& Moshfegh, B., Excess heat from kraft pulp mills: Trade-offs between internal and external use in the case of sweden-part 2: Results for future energy market scenarios. Energy Policy, 36(11), 4186-4197, 2008.

[49] Kalashnikov, V., Gulidov, R., \& Ognev, A., Energy sector of the Russian far east: Current status and scenarios for the future. Energy Policy, 2009.

[50] Keles, D., Möst, D., \& Fichtner, W., The development of the German energy market until 2030-A critical survey of selected scenarios. Energy Policy, 39(2), 812-825, 2010.

[51] Kemfert, C., \& Truong, T., Corrigendum to "impact assessment of emissions stabilization scenarios with and without induced technological change", Energy Policy, 36(6), 2292, 2008.

[52] Krewitt, W., Simon, S., Graus, W., Teske, S., Zervos, A., \& Schäfer, O.. Corrigendum to "the $2{ }^{\circ} \mathrm{C}$ scenario-A sustainable world energy perspective". Energy Policy, 36(1), 494, 2008.

[53] Krewitt, W., Simon, S., Graus, W., Teske, S., Zervos, A., \& Schäfer, O., The $2{ }^{\circ} \mathrm{C}$ scenario-A sustainable world energy perspective. Energy Policy, 35(10), 4969-4980, 2007.

[54] Krewitt, W., Nitsch, J., Fischedick, M., Pehnt, M., \& Temming, H., Market perspectives of stationary fuel cells in a sustainable energy supply system - long-term scenarios for germany. Energy Policy, 34(7), 793-803, 2006.

[55] Krey, V., Martinsen, D., \& Wagner, H., Effects of stochastic energy prices on long-term energy-economic scenarios. Energy, 32(12), 2340-2349, 2007.

[56] Li, L., Chen, C., Xie, S., Huang, C., Cheng, Z., Wang, H., et al., Energy demand and carbon emissions under different development scenarios for shanghai, china. Energy Policy, 2009.

[57] Madlener, R., Kowalski, K., \& Stagl, S., New ways for the integrated appraisal of national energy scenarios: The case of renewable energy use in Austria. Energy Policy, 35(12), 60606074, 2007.

[58] Martins, F. R., Rüther, R., Pereira, E. B., \& Abreu, S. L., Solar energy scenarios in brazil. part two: Photovoltaics applications. Energy Policy, 36(8), 2855-2867, 2008.

[59] Martins, F. R., Pereira, E. B., Silva, S. A. B., Abreu, S. L., \& Colle, S., Solar energy scenarios in brazil, part one: Resource assessment. Energy Policy, 36(8), 2843-2854, 2008.

[60] Mendoza, Y., Masera, O., \& Macias, P., Long-term energy scenarios for Mexico: Policy options for carbon savings and main barriers. Energy Policy, 19(10), 962-96, 1991.

[61] Mustonen, S. M., Rural energy survey and scenario analysis of village energy consumption: A case study in lao people's democratic republic. Energy Policy, 38(2), 1040-1048, 2010.

[62] Naidu, B. S. K., Indian scenario of renewable energy for sustainable development. Energy Policy, 24(6), 575-581, 1996.

[63] Onn, L. K., The Malaysian energy scenario. Energy, 8(1-2), 125-131, 1983.

[64] Oppenheimer, P., The new Europe and the Middle East: Scenarios for energy planning. Energy Policy, 18(9), 798-805, 1990.

[65] Ou, X., Zhang, X., \& Chang, S., Scenario analysis on alternative fuel/vehicle for china's future road transport: Lifecycle energy demand and GHG emissions. Energy Policy, 38(8), 3943-3956, 2010.

[66] Parikh, J. K., The emperor needs new clothes: Long-range energy-use scenarios by IIASA-WEC and IIPCC. Energy, 23(1), 69-70, 1998. 
[67] Phdungsilp, A., Integrated energy and carbon modeling with a decision support system: Policy scenarios for low-carbon city development in Bangkok. Energy Policy, 38(9), 4808-4817, 2010.

[68] Phdungsilp, A., Integrated energy and carbon modeling with a decision support system: Policy scenarios for low-carbon city development in Bangkok. Energy Policy, 2009.

[69] Renn, O., Social assessment of waste energy utilization scenarios. Energy, 28(13), 1345-1357, 2003.

[70] Saddler, H., Diesendorf, M., \& Denniss, R., Clean energy scenarios for Australia. Energy Policy, 35(2), 1245-1256, 2007.

[71] Sartori, I., Wachenfeldt, B. J., \& Hestnes, A. G., Energy demand in the Norwegian building stock: Scenarios on potential reduction. Energy Policy, 37(5), 1614-1627, 2009.

[72] Schiffer, H. W., WEC energy policy scenarios to 2050. Energy Policy, 36(7), 2464-2470, 2008.

[73] Schipper, L., \& Meyers, S., Using scenarios to explore future energy demand in industrialized countries. Energy Policy, 21(3), 264-275, 1993.

[74] Schuler, A., Weber, C., \& Fahl, U., Energy consumption for space heating of west-German households: Empirical evidence, scenario projections and policy implications. Energy Policy, 28(12), 877-894, 2000.

[75] Schulz, T. F., Kypreos, S., Barreto, L., \& Wokaun, A., Intermediate steps towards the $2000 \mathrm{~W}$ society in Switzerland: An energy-economic scenario analysis. Energy Policy, 36(4), 1303-1317, 2008.

[76] Shorrock, L. D., \& Dunster, J. E., The physically-based model BREHOMES and its use in deriving scenarios for the energy use and carbon dioxide emissions of the UK housing stock. Energy Policy, 25(12), 1027-1037, 1997.

[77] Shrestha, R. M., Malla, S., \& Liyanage, M. H., Scenario-based analyses of energy system development and its environmental implications in Thailand. Energy Policy, 35(6), 3179-3193, 2007.

[78] Siddiqi, T. A., Foell, W. K., Hills, P., Keesman, A. T., Nagao, T., \& Torok, S. J., Climate change and energy scenarios in Asia-pacific developing countries. Energy, 16(11-12), 14671488, 1991.

[79] Simões, S., Cleto, J., Fortes, P., Seixas, J., \& Huppes, G., Cost of energy and environmental policy in Portuguese $\mathrm{CO} 2$ abatement-scenario analysis to 2020. Energy Policy, 36(9), 3598-3611, 2008.

[80] Spena, A., Exergy analysis of the influence of primary energy sources scenario on design and management of pumpedstorage powerplants. Energy, 8(10), 741-748, 1983.

[81] Thiel, C., Perujo, A., \& Mercier, A., Cost and CO2 aspects of future vehicle options in Europe under new energy policy scenarios. Energy Policy, 38(11), 7142-7151, 2010.

[82] Turton, H., ECLIPSE: An integrated energy-economy model for climate policy and scenario analysis. Energy, 33(12), 17541769, 2008.

[83] Vaillancourt, K., Labriet, M., Loulou, R., \& Waaub, J., The role of nuclear energy in long-term climate scenarios: An analysis with the world-TIMES model. Energy Policy, 36(7), 2296-2307, 2008.

[84] Van Buskirk, R., Analysis of long-range clean energy investment scenarios for Eritrea, east Africa. Energy Policy, 34(14), 1807-1817, 2006.

[85] Van Ettinger, J., Sustainable use of energy. A normative energy scenario: 1990-2050. Energy Policy, 22(2), 111-118, 1994.

[86] van Vuuren, D., Fengqi, Z., de Vries, B., Kejun, J., Graveland, C., \& Yun, L., Energy and emission scenarios for China in the
21 st century - exploration of baseline development and mitigation options. Energy Policy, 31(4), 369-387, 2003.

[87] Winkler, H., Hughes, A., \& Haw, M., Technology learning for renewable energy: Implications for South Africa's long-term mitigation scenarios. Energy Policy, 37(11), 4987-4996, 2009.

[88] Worrell, E., \& Price, L., Policy scenarios for energy efficiency improvement in industry. Energy Policy, 29(14), 1223-1241, 2001.

[89] Zhang, Q., Tian, W., Zheng, Y., \& Zhang, L., Fuel consumption from vehicles of china until 2030 in energy scenarios. Energy Policy, 38(11), 6860-6867, 2010.

[90] Zhang, Q., Weili, T., Yumei, W., \& Yingxu, C., External costs from electricity generation of china up to 2030 in energy and abatement scenarios. Energy Policy, 35(8), 4295-4304, 2007.

[91] McDowall W., Eames M., Forecasts, visions, backcasts and roadmaps to the hydrogen economy: A review of the hydrogen futures literature, Energy Policy, 1236 - 1250, 2006.

[92] Jeffer A., Schwienfort W., Building scenarios with Fuzzy Cognitive Maps: An exploratory study of solar energy, Futures, 43, $52-66,2011$.

[93] Robert J., Lennert M., Two scenarios for Europe: "Europe confronted with high energy prices" or "Europe after Oil peaking", Futures, 42, 817 - 824, 2010.

[94] Huss W., R., Honton E., J., Scenario planning - What style should you use? Long Range Planning, 20, 21 - 29, 1987.

[95] Floyd J., Towards and Integral renewal of systems methodology for futures studies, Futures, 40, 138 - 149.

[96] Schwartz P., The Art of the Long View, Doubleday, 1991

[97] Ringland G., Scenario Planning, Wiley \& Sons, 1998

[98] Wack P., Scenarios: Shooting the rapids, Harvard Business Review, 139 - 150, 1985.

[99] Vietor R., Energy Policy in the America Since 1945: A Study of Business-Governmental Relations, Cambridge University Press, 1984.

[100] Thomas S., Evaluating the British Model of electricity deregulation, Annals of Public and Cooperative Economics, 75, $367-398$.

[101] Vietor R., Contrived Competition: Regulation and Deregulation in America, Harvard University Press, 1996.

102] Bergman L., et al., Europe's Network Industries: Conflicting Priorities, Centre for Economic Policy Research, 1998.

[103] Clingendael International Energy Program, Energy company strategies in the dynamic EU energy market (1995 - 2007), 2010.

[104] Thomas S., The Seven Brothers, Energy Policy, 31, 393 - 403, 2003

[105] Burch D., Burnett-Kant E., Unbundling the unbundled, McKinsey Quarterly, no 4, 2001.

[106] Walsh P., R., Sanderson S., M., Hybrid strategic Thinking in deregulated retail energy markets, International Journal of Energy Sector Management, 2, 218 - 230, 2008

[107] Lassila J., et al., Unbundling of operation and network development activities in electricity distribution, International Journal of Energy Sector Management 3, issue 4, 383 - 405, 2009

[108] DuMoulin H., Eyre J., Energy Scenarios - a learning process, Energy Economics, 73 - 86, 1979.

[109] Peltzman S., Winston C., Deregulation of Network Industries What's next?, American Enterprise Institute of Public Policy Research, Washington, 1992.

[110] Viscusi W., K., Vernon J., M., Harrington J., E., Economics of Regulation and Antitrust, $3^{\text {rd }}$ ed, MIT Press, Cambridge, 2001. 
[111] Trebing, H., M., A critical assessment of electricity and natural gas deregulation, Journal of Economic Issues, 42, 469 - 477, 2008

[112] Baudru D., Rigamonti E., The Strategies of the key players and deregulation of the gas and electricity markets in Europe, Revue de l'Energie, 439-450, 1998

[113] Percebois J., Nykouki E., Electricity and gas deregulation: a comparative approach within the EU, Revue de l'Energie, 369 $-376,1998$.

[114] Argyrpoulos G., Sakellaris J, Participation of the Private Sector, of the Public Sector and of the Non Governmental
Organizations to the global deregulation process of the Energy Markets, Sustainable world, 7, Xi - XX, 2003.

[115] Taylor R., Bogach V., S.,, China, A Strategy for International Assistance to Accelerate Renewable Energy Development, World Bank Discussion Paper 338, 1998.

[116] Zengming Z., et al., Renewable Energy Development in China, The Potential and the Challenges, China Sustainable Energy Program. 